AUTOR:

José Augusto Santos ${ }^{1}$

Natércia Maria Rodrigues ${ }^{2}$

${ }^{1} \mathrm{CIFI}^{2} \mathrm{D}$, Faculdade de Desporto

Universidade do Porto, Portugal

${ }^{2}$ Faculdade de Desporto

Universidade do Porto, Portugal

\section{Desporto adaptado.}

Quais os valores

que o devem nortear?

PALAVRAS CHAVE:

Desporto adaptado. Valores.

https://doi.org/10.5628/rpcd.12.03.128

\title{
RESUMO
}

O desporto adaptado deve ser assumido como um modelo cultural total que respeita as limitações dos seus intervenientes. Ser adaptado não significa estar reduzido de importância sociológica ou desportiva. Antes pelo contrário, a adaptação visa somente respeitar as limitações óbvias de cada tipo de deficiência mas permitir a excelência desportiva através da realização das máximas performances. 0 desporto adaptado, tal como todo o desporto, deve ser analisado numa perspetiva de grau ou nível de desenvolvimento.

Uma criança que nasce com ou adquire algum tipo de handicap ou condicionamento psico-motor deve chegar ao desporto adaptado pela via pedagógica e do desenvolvimento físico-desportivo. No entanto, quanto a pulsão pela excelência a toca, ou nasce com ela, deve-lhe ser permitido desenvolver a dimensão das suas capacidades enquadrando níveis de treino e de competição que lhe permitam ter no desporto uma forma elevada de realização desportiva e humana.

A este nível, ganhar uma maratona em cadeira de rodas ou a correr tem a mesma importância desportiva e humana. Urge assumir isso como desiderato social. 
Adapted sport.

Which values should guide it?

\section{ABSTRACT}

The adapted sport should be taken as a total cultural model that respects the limitations of its stakeholders. When the sport is adapted does not mean being reduced in sociological or sportive importance. Rather, the adaptation is intended only to meet the obvious limitations of each type of impairment but allow sporting excellence by taking the maximum performances. The adapted sport as the sport as an all, should be analyzed from a perspective of the degree or level of development.

A child who is born with or acquires some kind of handicap or psycho-motor conditioning must reach the adapted sport via educational and physical development. However, as the drive for excellence touches him or her, conditions must be created to permit their fully development respecting the level of their maximal capabilities. Then, training and competition frameworks must be create to enable them to take the sport a higher form of sporting achievement and human realization.

At this level, winning a marathon in a wheelchair or running has the same sportive and human importance. Urge take it as social desideratum.

\section{KEY WORDS:}

Adapted sport. Values. 


\section{O DESPORTO ADAPTADO...}

O desporto adaptado em Portugal, além de ser atravessado pelos estigmas que caracterizam o desporto em geral, e que são o reflexo da forma como a sociedade valoriza a prática desportiva, ainda arrosta uma série de condicionantes que the são próprias e que são a base das múltiplas indefinições que o caracterizam.

Antes de tentarmos perspetivar a validação social e axiológica do desporto adaptado, vamos fazer uma viagem ao âmago desse fenómeno social cada vez mais pregnante que é o desporto sensu latu, com a preocupação de vislumbrar os contornos que the dão significado.

Qual é o sentido último do desporto? É a competição.

A competição é consubstancial à vida e por consequência ao homem. Emerge da própria biologia e atravessa, indelével, todas as dimensões da realidade física e mental do homem.

A competição põe em jogo as capacidades adaptativas do ser. A vida arrisca. Quando não arrisca estagna e fenece. A evolução filogenética das espécies consubstancia a resposta aos problemas colocados pelo envolvimento. Para haver evolução é necessário existir luta, competição e por vezes cooperação. Por isso o desporto é uma metáfora perfeita da vida pois pressupõe, em ciclos subsequentes ou isocrónicos, o âgon e a cooperação.

0 desporto é, em grau superlativo, um sistema de realização de competências motoras de acordo com padrões e critérios de avaliação. 0 grau de validação do êxito desportivo varia em função do nível de competência motriz. Para uns, ganhar-se a si próprio ou ao amigo já é suficiente. Outros, os atletas de elite, pretendem voar mais alto e só têm o céu como limite - ser campeão do mundo ou vencedor dos jogos olímpicos. Os padrões e critérios de validação da atividade poderão ser os mesmos em termos ontológicos mas, diferindo em grau, induzem efeitos radicalmente diferentes em termos sociológicos.

A dimensão absoluta do feito desportivo acompanha a par e passo o desporto adaptado. A essência primordial da gesta desportiva é o feito absoluto. Ser o melhor. A procura do êxito absoluto, para quase todos, consubstancia a procura do "santo graal", perdido em terras de sonho e mistério.

A meta utópica de realização desportiva individual é ser campeão olímpico ou do mundo. Num outro plano conseguir o recorde mundial. Estes desideratos estão cometidos a muito poucos. E o ser normal sem genes de campeão, não terá direito também à sua procura de excelência?

Sem dúvida que sim. Níveis menores de realização desportiva podem funcionar como catalisadores de realização individual e promotores de auto-estima, tanto ou mais eficazmente que títulos mundiais ou olímpicos. Nesse caso, a atitude perante a prática desportiva terá de descentrar-se do êxito absoluto e fixar-se na validação ontológica que começa no Ser individual e nele termina. 0 meu êxito desportivo é algo que só a mim diz respeito pois só eu sei quais as metas que me propus atingir e como determinaram o grau do meu empenhamento. 
Quando o desporto não é alienação mas sim cultura, a consciência dos limites é ponto de partida para a erradicação de frustrações e angústias, funcionando o desporto como mais um meio que dispomos para ganhar vida, para ser vida, para nos encontrarmos mais a nós na emulação recorrente com os outros, nunca esquecendo o desiderato final de toda a competição desportiva - ganhar.

A partir daí as metas são mais difíceis de atingir porque não existem benesses materiais como recompensa mas única e simplesmente a saga heróica do homem em viver mais e mais intensamente a vida. A procura do desiderato de ir mais longe. Nessa procura, raramente as benesses materiais são recompensa suficiente.

Para isso o desporto tem de ser assumido de forma diferente. Não mais poderá ser considerado como atividade marginal, catártica, marcada pelo estigma da competição exacerbada e desumanizante. A competição desportiva, para exprimir toda a sua força humanística, deve respeitar no homem as suas particularidades, dirigidas à consecução do mais elevado rendimento.

Portador de uma vocação estética e ética que ultrapassa largamente o domínio físico onde se exprime, o desporto deverá assegurar, pelo equilíbrio da personalidade e a formação do carácter, a defesa do humano numa civilização cada vez mais mecanizada. Meio ideal de lazer e cultura, o desporto terá de ser a tábua de salvação das gerações vindouras para as quais o trabalho físico será imagem difusa, perdida nas poeiras dos relatos históricos.

Por isso, o desporto como cultura está impregnado de sentido político e, como política, deve visar melhorar a vida da pólis e não lançar sobre esta nuvens da desagregação ou segregação.

Logo após a revolução de Abril, alguns pseudo-intelectuais davam o apagamento e eventual destruição do futebol profissional português como facto irreversível, em virtude de ser uma fonte de alienação e de desvio do homem revolucionário no seu afã de porfiar pelos "amanhãs que cantassem". Não viam esses pensadores, na sua ligeireza analítica, impregnada pelos fumos passageiros da vulgata marxista, que não era o futebol que estava alienado mas sim a própria sociedade. Numa sociedade livre, plural e democrática não há desporto alienado. Numa sociedade aberta livre e democrática o desporto é uma forma, culturalmente elevada, de abrir horizontes.

Qual o horizonte que nos deve servir como utopia? Encontrar formas, cada vez mais humanas, de Ser (no sentido mais profundamente ontológico) numa sociedade marcada por focos imensos de desagregação. Uma das vias mais privilegiadas para elevar o Ser, nas múltiplas expressões que o caracterizam, pode ser a via desportiva.

$\mathrm{O}$ desporto pode ser um campo único de encontro humano numa atmosfera de convivialidade em que a festa, o humor, o riso, o aplauso, o grito e a alegria sejam formas socializantes e eticamente aceitáveis de sermos mais felizes.

Podemos competir como processo de elevação pessoal e social, aceitando como natural a emergência da hierarquização de valores. 0 que é de condenar não é a competição mas o que ela acarreta de sonegação de afirmação ontológica para o vencido, muito por culpa 
dos mass media que somente valorizam o triunfo, não cuidando de saber que existem segundos lugares com maior valia social, ética e desportiva, que muitas vitórias.

Uma competição ética e socialmente aceitável deve ter como pano de fundo relacional a gratidão:

- Agradeço-te adversário porque me permitiste competir, e ao ganhar-te afirmar a excelência da minha arte; por isso não sou mais do que tu, nem te ganho vantagem ontológica; neste momento fui melhor, amanhã posso ser eu a perder, e da mesma forma que hoje não te retiro dignidade humana amanhã acontecerá o mesmo contigo.

É esta a dimensão que pretendemos para o desporto adaptado que deve ser assumido $a b$ initio sem sofismas.

De posse dos instrumentos conceptuais que validem uma prática desportiva correcta, importa agora tentar elaborar a práxis do desporto adaptado que pretendemos.

0 desporto adaptado antes de tudo é desporto, procura de vitória, aspiração de excelência.

Reconhecemos o pouco empenhamento social de transformar o desporto adaptado em fenómeno de massas plenamente mediatizado e campo fértil para todos os aproveitamentos económicos. 0 desporto de alta competição é um catalisador excelente de publicidade; o desporto adaptado de alta competição também o pode e deve ser. 0 desporto de alta competição pode existir em várias dimensões absolutas. Daí o êxito das competições para veteranos. Tomemos como exemplo o corredor indiano Fauja Singh, atleta excecional que desafiou todos os conceitos de limite. Aos 94 anos completou a maratona de Londres em 5:40. Seis anos mais tarde, tornou-se o primeiro centenário a cumprir a prova mais mítica do calendário desportivo internacional, finalizando a maratona de Toronto em 8:11:06. Este atleta, paralelamente aos grandes campeões absolutos, é subsidiado pela Adidas e um dos seus ex-libris desportivos ao lado de David Beckham e Muhammad Ali.

Maratona prova iniciática com muito de mítico e algo de religioso. Provação física como elemento de elevação espiritual considerada por alguns como "a prova maldita". Há muitos anos atrás, o Prof. Moniz Pereira, "pai" do primeiro campeão olímpico português na maratona, proclamava que devido às excessivas e perigosas exigências de ordem fisiológica "a maratona não devia existir". Esta prova é, hoje em dia, um meio excecional de procura de realização e excelência para muitos desportistas portadores de deficiência.

Nenhuma competição desportiva tem a força mítica, histórica e humana da corrida da maratona. Cumpri-la, é o Eldorado funcional de muito corredor, qualquer que seja o seu nível performativo. Ganhá-la, é o encontro com o Santo Graal, só acessível aos eleitos, sejam estes atletas normais ou especiais.

Tal como para Fauja Singh, o absoluto para cada atleta com deficiência releva da sua especificidade motora, anatómica, funcional. Para todos, a procura de excelência justifica a dor das cargas, a frugalidade das dietas, o controlo dos descansos, a perda de outras realizações. 
$\mathrm{Na}$ Maratona de Londres de 2010, o canadiano Josh Cassidy, em cadeira de rodas, corta a meta em 1:37:01 enquanto correndo, o etíope Tsegaye Kebede, cumpriu a mesma distância em 2:05:19. Ambos mereceram subir às altas montanhas e olhar as águias nos olhos como fez Zaratustra. Ambos foram excelentes. Ambos competiram e ganharam. Ambos mereceram reconhecimento social. Ambos mereceram prebendas. Ambos mereceram ver o seu feito proclamado pelos arautos olímpicos. Ambos ganharam o direito a estátua na cidade. Em ambas as cabeças devem luzir os ramos de oliveira.

Só assim concebemos o desporto adaptado, competindo com o dito normal na importância social, na força desportiva, no respeito político.

Por isso, urge denunciar que não existe desporto adaptado em Portugal, mas sim uma prática desportiva circunstancial, mais ou menos enquadrada, visando uma participação competitiva esporádica. Esta prática não é o resultado dum empenhamento contínuo, sistemático e exclusivo, que mobilize toda a sociedade numa perspectiva de procura da excelência. No desporto adaptado deve haver discriminação positiva. Os melhores devem receber apoios e subsídios eficientes para realizarem o nível das suas potencialidades. Os medíocres e suficientes devem ser enquadrados numa perspectiva de lazer com os apoios inerentes ao desporto de massas. Não podemos desvirtuar a essência do desporto de alta competição - criar qualidade, produzir excecionalidade.

Por isso, urge fazer a segunda denúncia: não existem condições físicas e materiais para existir desporto adaptado de elevada qualidade.

Por muitas boas vontades que se encontram espalhadas um pouco por todo o lado, nunca se elaborou um plano nacional de adaptação e apetrechamento das instalações desportivas que desse resposta às exigências específicas do desporto adaptado. Não se adaptam as condições aos desportistas, são os desportistas que se adaptam àquilo que não foi feito para eles.

Por outro lado, continua-se a considerar o desporto adaptado como terapêutica, como factor de integração social, numa perspectiva reducionista que urge ultrapassar. 0 desporto adaptado que nos sensibiliza é menos aquele dos atletas todos juntos a cortar a meta e mais aquele que permite evidenciar o sangue, suor e lágrimas do esforço desmedido. Esse é o desporto adaptado em que acreditamos, pois é essa a dimensão em que acredito no desporto dito normal. Já dizia Schopenhaeur que o sofrimento é o animal que nos transporta mais rapidamente à perfeição. É esse imperativo ético que se deve constituir como pano de fundo de todo o desporto, a fortiori, do desporto adaptado.

Assim, não se pode dar ao desporto adaptado tempos residuais de treino e competição. As mais elevadas performances só são conseguidas com treino estenuante e competição exigente. Por isso, é forçoso discriminar lazer e competição, dando à competição a dignidade social que merece já que só diz respeito a um escol de eleitos.

Urge desenvolver uma cultura desportiva específica do desporto adaptado, criando novos nexos a partir da compreensão dos limites funcionais de cada atleta. 
O desporto adaptado não pode ser visto como mera exercitação para melhoria de funcionalidades; deve ser considerado como um modelo cultural cada vez mais aprofundado e que releva da especificidade de cada grupo social.

Os Jogos Paralímpicos demonstram, pela sua expressão multitudinária, que cada vez mais o mundo valoriza a dimensão ética e estética do desporto adaptado. Mas atenção, os Jogos Paralímpicos não devem ser valorizados como modelo de humanismo piegas e redutor. São momentos de elevação da espécie humana na procura da excelência desportiva, daí emergindo o mais são humanismo que releva da capacidade do homem se ultrapassar, de acrescentar novos horizontes aos seus limites. Apesar de reduzido na sua dimensão física, o homo desportivus paralímpico alcandora-se aos patamares da transcendência através da competição desportiva. Só assim vale este desporto, como competição dura e pura e não convívio de mediocridades.

Só existirá desporto adaptado quando o adaptado for a mera circunstância e o desporto for o terreno fértil de transcendências. Para isso, os responsáveis políticos devem elaborar uma nova carta de direitos do atleta com deficiência, que outorgue direitos mas também obrigações, pois o investimento no desporto adaptado deve privilegiar a procura dos campeões e por arrasto levar tudo e todos atrás de si. 0 desporto adaptado de excelência deve ser o catalisador de todas as outras expressões desportivas. Só é desporto quando há competição; só compete quem quer ganhar; só ganha quem treina e se esforça; são esses que merecem ser apoiados de forma especial. Os outros, os atletas normais do desporto adaptado que se contentem em fazer o desporto suficiente para serem felizes e que tenham condições para isso. Esse desporto massificado é importante, mas o desporto em que acreditamos e que mexe com os cordelinhos das nossas mais profundas emoções, é aquele que nos permite ver um jovem com uma só perna, a saltar mais que o melhor português com as duas pernas. 